\title{
Corrigendum: The structural validity and measurement invariance across gender of the Brief Corporate Entrepreneurship Assessment Instrument
}

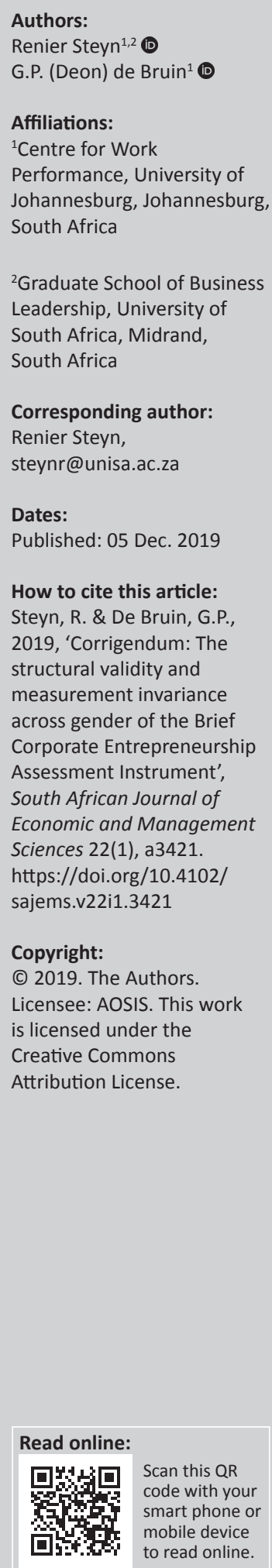

In the initial version of this article published earlier, the first author's affiliation was incorrect. The affiliation and acknowledgement sections are hereby corrected as follows:

Authors:

Renier Steyn ${ }^{1,2}$ (D)

G.P. (Deon) de Bruin ${ }^{1}$ (

\section{Affiliations:}

${ }^{1}$ Centre for Work Performance, University of Johannesburg, Johannesburg, South Africa

${ }^{2}$ Graduate School of Business Leadership, University of South Africa, Midrand, South Africa

\section{Acknowledgement}

This article stems from Renier Steyn's thesis, entitled 'Antecedents of innovation in organisations: A gender perspective' presented in partial fulfilment of the requirements for the $\mathrm{PhD}$ degree at the University of Johannesburg, Johannesburg, South Africa.

This correction does not alter the study's findings of significance or the overall interpretation of the study results. The author apologises for any inconvenience caused. 


\section{The structural validity and measurement invariance across gender of the Brief Corporate Entrepreneurship Assessment Instrument}

\begin{tabular}{|c|c|}
\hline \multicolumn{2}{|c|}{$\begin{array}{l}\text { Authors: } \\
\text { Renier Steyn }{ }^{1} \text { @ } \\
\text { G.P. (Deon) de Bruin }{ }^{2} \text { (D) }\end{array}$} \\
\hline \multicolumn{2}{|c|}{$\begin{array}{l}\text { Affiliations: } \\
{ }^{1} \text { Graduate School of Business } \\
\text { Leadership, University of } \\
\text { South Africa, South Africa }\end{array}$} \\
\hline \multicolumn{2}{|c|}{$\begin{array}{l}{ }^{2} \text { Centre for Work } \\
\text { Performance, University of } \\
\text { Johannesburg, South Africa }\end{array}$} \\
\hline \multicolumn{2}{|c|}{$\begin{array}{l}\text { Corresponding author } \\
\text { Renier Steyn, } \\
\text { steynr@unisa.ac.za }\end{array}$} \\
\hline \multicolumn{2}{|c|}{$\begin{array}{l}\text { Dates: } \\
\text { Received: } 02 \text { June } 2017 \\
\text { Accepted: } 30 \text { Mar. } 2018 \\
\text { Published: } 19 \text { June } 2018\end{array}$} \\
\hline \multicolumn{2}{|c|}{$\begin{array}{l}\text { How to cite this article: } \\
\text { Steyn, R. \& De Bruin, G.P., } \\
2018 \text {, 'The structural validity } \\
\text { and measurement invariance } \\
\text { across gender of the Brief } \\
\text { Corporate Entrepreneurship } \\
\text { Assessment Instrument', } \\
\text { South African Journal of } \\
\text { Economic and Management } \\
\text { Sciences 21(1), a1965. } \\
\text { https://doi.org/10.4102/ } \\
\text { sajems.v21i1.1965 }\end{array}$} \\
\hline \multicolumn{2}{|c|}{$\begin{array}{l}\text { Copyright: } \\
\text { ( ) 2018. The Authors. } \\
\text { Licensee: AOSIS. This } \\
\text { is licensed under the } \\
\text { Creative Commons } \\
\text { Attribution License. }\end{array}$} \\
\hline \multicolumn{2}{|l|}{ Read online: } \\
\hline 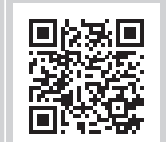 & $\begin{array}{l}\text { Scan this QR } \\
\text { code with your } \\
\text { smart phone or } \\
\text { mobile device } \\
\text { to read online. }\end{array}$ \\
\hline
\end{tabular}

Background: Corporate entrepreneurial activity and innovation are presented as essential elements of organisational success, and gender diversity is often seen as an important variable in this context. The efficient measurement of these variables is essential to the management thereof. It is within this context that the Brief Corporate Entrepreneurship Assessment Instrument (BCEAI) was developed. Shorter instruments seem to be favoured by researchers and practitioners alike. However, little is known about the psychometric properties of the $\mathrm{BCEAI}$, particularly regarding measurement invariance.

Aim: This study seeks to address the structural validity and measurement invariance for the BCEAI applied for men and women. The objective was to establish the utility of the instrument within the South African context, with specific emphasis on cross-gender comparisons.

Setting: Medium to large South African organisations, with more than 60 employees, were targeted for inclusion in the study. Once organisations indicated their willingness to participate, 60 employees per organisation were randomly selected to participate in the study.

Methods: Data on the BCEAI were captured and pairwise multi-group confirmatory factor analyses with robust maximum likelihood estimation were used to examine four levels of measurement invariance, as well as the equivalence of latent means pertaining to male and female respondents.

Results: Data were collected from 3180 employees representing 52 South African organisations. The results support the structural validity of the BCEAI and demonstrate strict measurement invariance for the BCEAI across gender. Equivalence of latent means across gender was also supported.

Conclusion: These results reveal that the BCEAI mirrors the structure of the original instrument in the South African context and that BCEAI yields psychometrically equivalent scores among employees of both genders. Researchers and practitioners can therefore use the BCEAI with the knowledge that its theoretical structure is sound and can apply it with confidence when comparing male and female employees in the workplace.

\section{Introduction}

This article addresses the important matter of the accurate assessment of the entrepreneurial environment within organisations, as perceived by employees. This topic is important as organisational success is dependent on innovation, and the accurate assessment of the entrepreneurial environment, which fosters such behaviour, is necessary should any interventions be planned. The issue is complicated by the debate about gender differences as far as innovation is concerned, and it may therefore be asked if men and women perceive the organisational environment in the same manner. This study will focus on the lastmentioned matter.

The focus on gender in the assessment of the entrepreneurial environment stems from the comparisons often drawn between men and women. Although numerous attempts have been made to explain differences in men's and women's attitudes and intentions, the extent to which these differences are due to the assessment thereof is less often considered. It may well be asked if these differences are real, or whether the measuring instruments do not function equivalently for men and women. In some cases, instruments have indeed been found to function differently for men and women (Pässler, Beinicke \& Hell 2014; Wetzel et al. 2013), while in other cases no such differentiation was noted (Baker, Caison \& Meade 2007; Wei et al. 2014). Within the context of 
entrepreneurship, Zampetakis et al. (2017) report that gender differences, at the item level, regarding entrepreneurial attitudes, perceived behavioural control, subjective norms and entrepreneurial intentions, are almost non-existent and negligible. However, ignoring the possibility of deferential functioning has the potential to compromise any substantive gender-based comparisons resulting from the measurement (Salzberger, Newton \& Ewing 2014). More so, the National Institute of Education and American Psychological Association Standards lists differential validity and differential prediction as a major concern of test fairness (Pässler et al. 2014). Only once construct comparability (measurement invariance) is demonstrated does it become possible to interpret differences in test or scale scores as true representations of differences explained by group membership (Wu, Li \& Zumbo 2007).

In this research, structural validity and measurement invariance across gender of the Brief Corporate Entrepreneurship Assessment Instrument (BCEAI) was tested, using five consecutive hypotheses related to similar factor loading patterns, unstandardised loadings, intercepts, error variances and latent means. The objectives were to examine if the BCEAI structure could be replicated across gender groups, and to examine the level of measurement invariance attained across the groups. Evidence on the BCEAI deferential functioning across male and female respondents is not presently available. The aim of this study was to produce such evidence, focusing on medium to large South African organisations, gathering data from random employee samples.

The literature review follows, focusing primarily on the characteristics of the Corporate Entrepreneurship Assessment Instrument (CEAI; Hornsby, Kuratko \& Zahra 2002). The literature review starts by explaining the importance of entrepreneurship and an entrepreneurial climate to organisational success. This is followed by a detailed discussion of the CEAI's psychometric properties, as well as some data collected on the BCEAI by Strydom (2013). Attention then shifts towards gender differences and the literature review is concluded with a discussion of the concept of measurement invariance. The method used in the study is provided, followed by a presentation of the empirical results. The obtained results are then discussed and the limitations of the research acknowledged. Lastly, conclusions are drawn on the structural validity and gender-specified measurement invariance of the BCEAI, given this sample.

\section{Literature review}

Organisational performance is an imperative indicator of organisational success and one of the most important key variables in management research (Stegerean \& Gavrea 2010). Research indicates that organisational performance is affected by innovation (e.g. Durán-Vázquez, Lorenzo-Valdés \& Moreno-Quezada 2012; Likar, Kopa \& Fatur 2014; Nybakk \& Jenssen 2012; Oke, Walumbwa \& Myers 2012). It is important for organisations to undertake research on the antecedents to innovation so as to allow managers to take note of the potency of different predictors of organisational performance, as well as to manage these in an effective manner (Bigliardi 2013; Ndregjoni \& Elmazi 2012). Yen (2013) also makes this link and states that the facilitation of innovation is an essential management function which is directly linked to organisational performance.

An important element with regard to innovation is organisational climate (Nusair 2013; Panuwatwanich, Stewart \& Mohamed 2008). Some scholars (e.g. Björkdahl \& Börjesson 2011; Lin \& Liu 2012; Zhang \& Begley 2011) have reported a distinct relationship between organisational climate and innovation. According to Hamidianpour et al. (2015), organisational climate denotes the employee's perceptions about the organisation's reward system, leadership credibility, organisational policy and its formal and informal procedures - as well as, ultimately, his or her sense of belonging in and trust of the organisation. Along similar lines, Padmaja (2014) argues that organisational climate includes the provision of challenging jobs to employees, the provision of a good working environment, the creation of acceptable career paths and the leadership styles adopted in the organisation, including participation in decision-making.

Hornsby et al. (2002) are important authors with regard to the conceptualisation and measurement of organisational climate associated with innovation in the workplace. The Hornsby et al. (2002) measure of entrepreneurial climate (CEAI) is often both referred to and used (Bhardwaj 2012; Brazeal, Schenkel \& Kumar 2014; De Villiers-Scheepers 2012; Hajipour \& Mas'oomi 2011; Holt, Rutherford \& Clohessy 2007; Hornsby et al. 2013; Karimi et al. 2011; Kuratko \& Audretsch 2013; Marzban, Seyed \& Ramezan 2013; Nikolov \& Urban 2013). This instrument measures five constructs typically found in organisational climate surveys, namely the level of management support, work discretion/ autonomy, rewards and reinforcement, time availability and organisational boundaries (Hornsby et al. 2002).

The focus of this research was on investigating the validity of the BCEAI, a truncated version of the CEAI, proposed by Strydom (2013), specifically with reference to measurement invariance across gender. The validity of cross-gender comparisons is important in assisting to address philosophical issues, such as the fundamental feminist philosophical questions, which include assertions that women are equal to men, different from men, or superior to men (Mikkola 2016). Another reason for investigating the invariance in crossgender comparisons is the numerous studies that proclaim that such differences, based on group membership, exist in the workplace. Authors suggest, for example, that there are significant differences between men and women with regard to how they manage and express stress and emotions (Bennie \& Huang 2010). Authors also suggest variations based on group differences with regard to health or safety risks in the workplace (Mühlau 2011), differences concerning interest in communal factors (Frame et al. 2010), as well as differences in 
work scheduling (Cascio 2015; Robbins \& Judge 2011). Important within the context of this research is the role that gender plays in organisational innovation. While some researchers have found a link between gender diversity and innovation in the workplace (Adams \& Ferreira 2009; Deloitte 2013; Francoeur, Labelle \& Sinclair-Desgagné 2008; Jiménez, Fuentes-Fuentes \& Ruiz-Arroyo 2014), research also suggests that this does not occur in all situations (McMahon 2010; Parrotta, Pozzoli \& Pytlikova 2014). Sonfield et al. (2001), as well as Kvidal and Ljunggren (2014), found no differences. The last mentioned report actually states that gender is a non-issue in terms of innovation. The research referred to in this paragraph affirms the use of gender as a variable in the work and innovation environment. In addition, the mixed findings point to a need for further research, including the investigations regarding methodology, measurement, and the validity of measurement - which constitutes the focus of this research.

The CEAI (Hornsby et al. 2002) was used as a basis to develop BCEAI. As mentioned earlier, the CEAI measures five constructs, namely the level of management support, work discretion or autonomy, rewards and reinforcement, time availability, and organisational boundaries (Hornsby et al. 2002). Considerable work has been published on the factor structure and reliability of the CEAI. Hornsby et al. (2002) reported a five factor CEAI solution, which yielded Cronbach's alpha coefficients of $0.92,0.86,0.75,0.77$ and 0.69 for management support, discretion or autonomy, rewards and reinforcement, time availability and organisational boundaries respectively. The results did not fully support organisational boundaries as an important factor as it marginally failed to meet the set threshold of $\alpha=0.70$. Kamffer (2004) reported alphas of 0.88, 0.80, 0.62, 0.71, and 0.77 for management support, discretion or autonomy, rewards and reinforcement, time availability and organisational boundaries respectively. In this study, rewards and reinforcement did not meet the 0.70 threshold. An analysis of the CEAI by Holt et al. (2007) demonstrated support for four factors: management support, work discretion or autonomy, rewards and reinforcement and time availability. The coefficient alphas of these factors were 0.92 , $0.91,0.82$, and 0.77 respectively. Again, organisational boundaries failed to meet the 0.70 threshold.

The questionnaire used in this study, as proposed by Strydom (2013), consisted of 20 items. The length of the CEAI (i.e. 48 items) triggered the development of the BCEAI (Strydom 2013). In a similar manner to the CEAI, the BCEAI proposes a hierarchical structure with each of the five factors consisting of four items (see Table 1). The items were selected from the original questionnaire, based on the individual item factor loadings on the particular targeted factor (Strydom 2013). The four items with the highest loading per factor were retained, based on the Hornsby et al. (2002) findings. The aspiration was that the BCEAI would yield psychologically equivalent factors to the CEAI, with acceptable reliabilities.
TABLE 1: Constructs and items of the Brief Corporate Entrepreneurship Assessment Instrument.

\begin{tabular}{|c|c|c|}
\hline Construct & Number & Item \\
\hline \multirow[t]{4}{*}{$\begin{array}{l}\text { Management } \\
\text { support }\end{array}$} & 1 & $\begin{array}{l}\text { Individual risk takers are often recognised for their } \\
\text { willingness to champion new projects, whether } \\
\text { eventually successful or not. }\end{array}$ \\
\hline & 2 & $\begin{array}{l}\text { People are often encouraged to take calculated } \\
\text { risks with new ideas around here. }\end{array}$ \\
\hline & 3 & $\begin{array}{l}\text { Many top managers have been known for their } \\
\text { experience with the innovation process. }\end{array}$ \\
\hline & 4 & $\begin{array}{l}\text { This organisation supports many small and } \\
\text { experimental projects realising that some will } \\
\text { undoubtedly fail. }\end{array}$ \\
\hline \multirow[t]{4}{*}{$\begin{array}{l}\text { Work discretion/ } \\
\text { autonomy }\end{array}$} & 5 & $\begin{array}{l}\text { It is basically my own responsibility to decide how } \\
\text { my job gets done. }\end{array}$ \\
\hline & 6 & I almost always get to decide what I do in my job. \\
\hline & 7 & I have the freedom to decide what I do in my job. \\
\hline & 8 & $\begin{array}{l}\text { I have much autonomy on my job and am left on } \\
\text { my own to do my own work. }\end{array}$ \\
\hline \multirow[t]{4}{*}{$\begin{array}{l}\text { Rewards/ } \\
\text { reinforcement }\end{array}$} & 9 & $\begin{array}{l}\text { My manager would tell his boss if my work was } \\
\text { outstanding. }\end{array}$ \\
\hline & 10 & $\begin{array}{l}\text { My supervisor will increase my job responsibilities } \\
\text { if I am performing well in my job. }\end{array}$ \\
\hline & 11 & $\begin{array}{l}\text { My supervisor will give me special recognition if } \\
\text { my work performance is especially good. }\end{array}$ \\
\hline & 12 & $\begin{array}{l}\text { The rewards I receive are dependent upon my } \\
\text { work on the job. }\end{array}$ \\
\hline \multirow[t]{4}{*}{ Time availability } & 13 & $\begin{array}{l}\text { I have just the right amount of time and workload } \\
\text { to do everything well. }\end{array}$ \\
\hline & 14 & $\begin{array}{l}\text { I feel that I am always working with time } \\
\text { constraints on my job. }\end{array}$ \\
\hline & 15 & $\begin{array}{l}\text { I always seem to have plenty of time to get } \\
\text { everything done. }\end{array}$ \\
\hline & 16 & $\begin{array}{l}\text { During the past } 3 \text { months, my work load was too } \\
\text { heavy to spend time on developing new ideas. }\end{array}$ \\
\hline \multirow[t]{4}{*}{$\begin{array}{l}\text { Organisational } \\
\text { boundaries }\end{array}$} & 17 & $\begin{array}{l}\text { I clearly know what level of work performance is } \\
\text { expected from me in terms of amount, quality and } \\
\text { timeliness of output. }\end{array}$ \\
\hline & 18 & In my job I have no doubt of what is expected of me. \\
\hline & 19 & There is little uncertainty in my job. \\
\hline & 20 & $\begin{array}{l}\text { In the past } 3 \text { months, I have always followed } \\
\text { standard operating procedures or practices to } \\
\text { execute my major tasks. }\end{array}$ \\
\hline
\end{tabular}

Source: Hornsby, J.S., Kuratko, D.F. \& Zahra, S.A., 2002, 'Middle managers' perception of the internal environment for corporate entrepreneurship: Assessing a measurement scale', Journal of Business Venturing 17(3), 253-273. https://doi.org/10.1016/S0883-9026(00)00059-8; Strydom, A.S., 2013, 'The influence of organisational behaviour variables on corporate entrepreneurship', Doctor of Business Leadership, University of South Africa, Pretoria, South Africa.

The CEAI items are presented as statements, such as the following: 'Individual risk takers are often recognised for their willingness to champion new projects, whether eventually successful or not'. Respondents respond to the statements on a standard Likert scale. A high score on any particular subscale would be suggestive of a climate that is favourable to entrepreneurial activity, and a low score would suggest circumstances that impede entrepreneurial activity. An overall high score would be indicative of the existence of a positive entrepreneurial climate. The five constructs, as well as the four items representing each of the constructs, are presented in Table 1.

The reliability of the subscales and the total questionnaire are reported by Strydom (2013) as 0.731, 0.825, 0.742, 0.689 , and 0.574 for management support, discretion or autonomy, rewards and reinforcement, time availability and organisational boundaries. As in previous research, organisational boundaries failed to meet the threshold of 0.70 . The reliability of the total scale was 0.810 . These reliabilities appear adequate for research purposes, but results with respect to the organisational boundaries scale 
need to be viewed with caution, given the low Cronbach's alpha value reported.

Strydom (2013) reported that the covariance of these items was adequately explained by five factors. Each item loaded on factors as expected and all factor loadings were higher than 0.50. No cross-loadings were observed. This would suggest that the BCEAI has factorial validity.

In the present study, the focus will be on whether the BCEAI (Strydom 2013) mirrors previous findings about the CEAI (Hornsby et al. 2002) in non-Western contexts and whether scores on these factors are comparable across gender groups. Some evidence with regard to the replicability of the CEAI structure in a Western context (Holt et al. 2007; Hornsby et al. 2002) is reported, while evidence in the non-Western context seems mixed, with Kamffer (2004) replicating the structure and Van Wyk and Adonisi (2011) failing to do so among African participants. To date, however, no study has comprehensively examined measurement invariance of the CEAI among employees across different gender groups. This is also true as far as the less-used BCEAI is concerned.

The matter of measurement invariance is central to this research. Measurement invariance relates to an observed score being reflective of an individual's standing on a construct, independent of their group membership (Mellenbergh 1989; Meredith 1993; Meredith \& Millsap 1992; $\mathrm{Wu}$ et al. 2007). Within the context of factor analysis, measurement invariance means that the same latent variables are measured on the same scale (metric) across groups, allowing for cross-group factor scores to be comparable (Meredith 1993; Wu et al. 2007). Multi-group confirmatory factor analysis is the de facto standard for use in investigating the degree to which measures are invariant across groups (Chen 2008).

Five consecutive hypotheses will be tested in this research. These are that men and women have: (1) similar factor loading patterns, (2) equal (unstandardised) factor loadings, (3) equal factor loadings and intercepts, (4) equal factor loadings, intercepts, as well as error variances and (5) equivalence of the latent means, when responding to BCEAI items.

\section{Method}

A cross-sectional survey design was used to generate data to test the structural validity and measurement invariance of the BCEAI across gender.

\section{Setting}

The target population was all employees. However, availability, accessibility, proximity and cost necessitated a focus on South African organisations. Only organisations with more than 60 employees were targeted. The setting was therefore medium to large organisations, based in South Africa, to which access was granted. All participants completed the BCEAI in English (which is the lingua franca of high school and post-school education, as well as of the business milieu, in South Africa).

\section{Instrument}

The BCEAI (Strydom 2013), as discussed in detail above, was used in the study.

\section{Procedure}

Within organisations random sampling was therefore done. Each fieldworker advised participants as to the nature of their participation. Those who agreed to participate then completed a hard copy of the questionnaire and handed it back to the respective fieldworkers. Most employees were willing to participate. Those unwilling to participate were replaced, using the same list from which the original 60 participants were drawn.

\section{Analysis}

Following the recommendations of Vandenberg and Lance (2000), pairwise multi-group confirmatory factor analyses (Wu et al. 2007) with robust maximum likelihood estimation were used to examine four levels of measurement invariance across men and women: (1) configural invariance (similar pattern of freely estimated and fixed factor loadings), (2) weak invariance (equal unstandardised factor loadings), (3) strong invariance (equal unstandardised factor loadings and intercepts) and (4) strict invariance (equal unstandardised factor loadings, intercepts, and error variances) (Vandenberg \& Lance 2000). As a final step, equivalence of the latent means of men and women on the five factors was tested.

\section{Ethical consideration}

Following receipt of permission from the Research Ethics Review Committee of the Graduate School of Business Leadership (GSBL) at the University of South Africa for the data to be collected, Master of Business Leadership (MBL) students were recruited as fieldworkers to collect data. They were requested to target relatively large organisations where they could have access to at least 60 employees who had a sufficient command of English to complete the instruments in a meaningful way - as the instruments were administered in English. The collection of organisations presented in this study was therefore the product of a convenient sample. Once approval to conduct the research within the organisations was obtained, a list of staff members was obtained from each organisation's human resource department and participants were selected randomly from the list.

\section{Results}

The participants were 3180 employees, representing 52 South African organisations. This study examines the BCEAI structure across 1771 men and 1372 women employees, with 37 participants providing incomplete information. Data were available across all of the companies concerned. 
TABLE 2: Chi-square test and change in chi-square statistics.

\begin{tabular}{|c|c|c|c|c|c|c|}
\hline Invariance level & Df & BIC & $x^{2}$ & $\Delta \chi^{2}$ & $\Delta \mathrm{df}$ & $\Delta p$ \\
\hline Configural & 320 & 173986 & 1322 & - & - & - \\
\hline Weak & 335 & 173908 & 1364 & 42.0 & 15 & 0.0002 \\
\hline Strong & 350 & 173830 & 1406 & 42.4 & 15 & 0.0002 \\
\hline Strict & 370 & 173694 & 1431 & 25.1 & 20 & 0.1973 \\
\hline Equal latent means & 375 & 173664 & 1441 & 9.4 & 5 & 0.0938 \\
\hline
\end{tabular}

BIC, Bayesian information criterion.

TABLE 3: Fit measures and changes in fit measures.

\begin{tabular}{lcccc}
\hline Invariance level & CFI & RMSEA & $\Delta$ CFI & $\Delta$ RMSEA \\
\hline Configural & 0.92 & 0.045 & - & - \\
Weak & 0.91 & 0.045 & 0.002 & 0.000 \\
Strong & 0.91 & 0.044 & 0.002 & 0.000 \\
Strict & 0.91 & 0.043 & 0.000 & 0.001 \\
Equal latent & 0.91 & 0.043 & 0.000 & 0.000 \\
means & & & & \\
\hline
\end{tabular}

$\mathrm{CFI}$, comparative fit index; RMSEA, root mean square error of approximation.

TABLE 4: Standardised factor loadings of the Brief Corporate Entrepreneurship Assessment Instrument items for men and women jointly.

\begin{tabular}{lccccc}
\hline Variable & \multicolumn{5}{c}{ Factor } \\
\cline { 2 - 7 } & $\begin{array}{c}\text { Management } \\
\text { support }\end{array}$ & $\begin{array}{c}\text { Work } \\
\text { discretion }\end{array}$ & Rewards & $\begin{array}{c}\text { Time } \\
\text { availability }\end{array}$ & $\begin{array}{c}\text { Organisational } \\
\text { boundaries }\end{array}$ \\
\hline i1 & 0.60 & - & - & - & - \\
i2 & 0.68 & - & - & - & - \\
i3 & 0.61 & - & - & - & - \\
i5 & 0.48 & - & - & - & - \\
i6 & - & 0.56 & - & - & - \\
i7 & - & 0.79 & - & - & - \\
i8 & - & 0.79 & - & - & - \\
i9 & - & 0.51 & - & - & - \\
i10 & - & - & 0.47 & - & - \\
i11 & - & - & 0.40 & - & - \\
i12 & - & - & 0.74 & - & - \\
i13 & - & - & 0.63 & - & - \\
i14 & - & - & - & 0.86 & - \\
i15 & - & - & - & 0.25 & - \\
i16 & - & - & - & 0.56 & - \\
i17 & - & - & - & 0.28 & - \\
i18 & - & - & - & - & 0.73 \\
i19 & - & - & - & - & 0.71 \\
$\mathrm{i} 20$ & - & - & - & - & 0.28 \\
\hline
\end{tabular}

Note: Values are rounded to two decimal places. All factor loadings are statistically significant $(p<0.05)$.

The distribution of participants with respect to race or ethnicity was as follows: $8.3 \%$ Asian people, $58.4 \%$ black people, $8.4 \%$ mixed race people, and $24.6 \%$ white people (missing data $=0.3 \%$ ). Participants' ages ranged between 20 and 72 years $(M=37.80, S D=9.11)$. Participants' tenure at their present companies ranged from 1 month to 42 years, with an average of 8.39 years $(\mathrm{SD}=7.47)$.

A preliminary analysis was performed to ensure that no violations of the assumptions of normality were committed. The skewness and kurtosis coefficients of the BCEAI items ranged between -1.08 and 0.45 for skewness, and -1.15 and 1.16 for kurtosis. Overall, the data appeared appropriate for factor analysis with maximum likelihood estimation.

Analyses were performed with the lavaan package (Rosseel 2012) in R (R Core Team 2013). In each group, a baseline independent cluster confirmatory factor analysis (IC-CFA) model was specified in accordance with the structure given in Table 1. The baseline models were identified by fixing the unstandardised factor loading of one item per targeted factor to reflect unity. Factor loadings of items on non-target factors were fixed to reach zero. Factor loadings of the remaining items, factor covariances and error variances were freely estimated using robust maximum likelihood. The maximum likelihood chi-square $\left(\mathrm{ML} \chi^{2}\right)$, Bayesian information criterion (BIC), comparative fit index (CFI) and root mean square error of approximation (RMSEA) were used to evaluate global fit.

According to the ML $\chi^{2}$ the hypotheses of perfect fit for all models were rejected $(p<0.001)$. However, the CFI suggested marginally good fit across all the models and the RMSEA suggested good fit.

Table 2 and Table 3 summarise the changes in fit across successively more stringent measurement invariance models with respect to the BIC, CFI and RMSEA. For each comparison, very small $\triangle \mathrm{CFI}$ and $\triangle$ RMSEA values were found $(\leq 0.002$ for all comparisons; see Table 3). The lowest RMSEA and BIC values were observed for the strict invariance model (i.e. equal loadings, intercepts and error terms), suggesting that this model has the best chance of being successfully replicated in future studies.

As a final step, we added the constraint of equal latent means across men and women, producing a statistically nonsignificant $\Delta \chi^{2}(p=0.094)$. In addition, the $\Delta$ CFI and $\Delta$ RMSEA values greater than 0.001 (see Table 3 ) indicated that the latent means of the male and female respondents could be treated as equal.

Against the background of the support yielded by the $\Delta \mathrm{CFI}$ and $\triangle$ RMSEA for strict measurement invariance, Table 4 shows the standardised factor loadings obtained for the total group $(n=3.143)$. Each factor was well defined and each item was a statistically significant $(p<0.001)$ and satisfactory indicator of its target factor. Three items with standardised factor loadings less than 0.30 were observed (i.e. Item 14 and Item 16 on the factor time availability, and Item 19 on the factor organisational boundaries).

The correlations between the factors ranged from 0.25 (work discretion and time availability) to 0.61 (management support and rewards) (see Table 5). The range of the Cronbach's alpha reliability coefficients of the BCEAI traits across the genders was 0.670 for men and 0.685 for women on management 
TABLE 5: Factor and scale correlations of the Brief Corporate Entrepreneurship Assessment Instrument.

\begin{tabular}{|c|c|c|c|c|c|}
\hline Variable & Managerial support & Work discretion & Rewards & Time availability & Organisational boundaries \\
\hline MS & $(0.68)$ & 0.29 & 0.41 & 0.13 & 0.24 \\
\hline WD & 0.36 & $(0.74)$ & 0.28 & 0.09 & 0.23 \\
\hline RW & 0.61 & 0.36 & $(0.64)$ & 0.11 & 0.27 \\
\hline TA & 0.32 & 0.25 & 0.33 & $(0.59)$ & 0.09 \\
\hline $\mathrm{OB}$ & 0.37 & 0.27 & 0.40 & 0.29 & $(0.57)$ \\
\hline
\end{tabular}

MS, Managerial support; WD, Work discretion; RW, Rewards; TA, Time availability; OB, Organisational boundaries.

Note: Factor correlations are below the diagonal. Scale correlations are above the diagonal. Coefficient alphas are on the diagonal and shown in brackets. Values are rounded to two decimal places. All correlations are statistically significant $(p<0.05)$.

support (4 items), 0.745 for men and also 0.745 for women on work discretion or autonomy (4 items), 0.652 for men and 0.616 for women on rewards and reinforcement $(4$ items), 0.573 for men and 0.606 for women on time availability (4 items) and 0.536 for men and 0.601 for women on organisational boundaries (4 items). The Cronbach's alpha reliability coefficients of the total BCEAI were 0.762 (20 items), with 0.762 for men and 0.755 for women respectively. The reliabilities of the five factors were uniformly similar in strength across the sexes and, given the evidence in support of strict measurement invariance, these reliabilities can be assumed to be invariant across the groups.

Across the groups, weak covariance between factors was observed, which points to the independence of the different factors.

\section{Discussion}

Due to the interest in gender as a differentiating variable in the workplace, and particularly the availability of statistical technology to test gender-based differences in responding to psychological testing, this study set out to test whether the BCEAI structure mirrors the CEAI in non-Western contexts and whether scores on these factors are comparable across gender groups. The results are discussed below, with specific reference to the theoretical and practical implications, as well as to the contribution of this study to the present body of knowledge.

According to the maximum likelihood chi-square test, the hypothesis of perfect fit for all the measurement models had to be rejected (see Table 2). However, the CFI and RMSEA values evidenced that the degree of misfit across the models was relatively small (see Table 3 ). The $\Delta$ CFI values in Table 3 revealed negligible deteriorations in fit across successively stringent levels of measurement invariance (note that the CFI does not take model complexity into account). The $\triangle$ RMSEA values showed improved fit with successively stringent models. Indeed, the RMSEA and BIC, which both take model complexity into account, showed that the strict measurement invariance model yielded the best fit (see Table 3). Taken together, these results suggest that a measurement model with invariant factor loadings, intercepts and error variances for men and women is likely to best replicate across different studies. The additional test of latent mean equality was also met, which supplements the notion of invariance. Overall, the results of this study indicated that despite differences in gender, participants responded to the items on the BCEAI in a similar manner.
This study contributes towards addressing limitations in the existing literature of innovation climate measurement as the results support the construct validity of the BCEAI elements among South African men and women. Strydom (2013) showed the replication of the CEAI/BCEAI structure in a heterogeneous (men and women combined) South African group. The results of the present study reflect additionally that strict measurement invariance is achieved, which implies that scores on the BCEAI can be compared across the gender groups. Moreover, the results also show equivalence of latent means scores across factors. This signals that the latent mean scores of men and women do not differ significantly, implying that any critique towards Strydom (2013) for neglecting gender as a moderator would be unfounded.

The results portray a picture contrary to the perception of certain individuals or groups who see gender as a differentiating factor in the entrepreneurial domain (e.g. Jiménez et al. 2014), but are considered to be aligned to the findings of other researchers (e.g. Kvidal \& Ljunggren 2014), who suggest gender to be a non-issue when predicting innovation. These empirical results could have repercussions for feminist philosophers and theory regarding gender, as the study does not report any significant differences in the ways men and women perceive this aspect in the workplace.

The results of this study also have implications for organisational assessment practices. Since strict measurement invariance was achieved, researchers and practitioners may use scores on the BCEAI to compare individuals across gender groups, knowing that the responses should not be affected by gender-based response biases.

Lastly, the replication results also permit researchers in South Africa to capitalise on existing theoretical and empirical knowledge about the CEAI (Hornsby et al. 2002). The Hornsby et al. (2002) structure of internal environment for corporate entrepreneurship is widely followed, with more than 1000 citations, and abundant knowledge has been created around their conceptualisation of the organisational environment. The knowledge about the replication of this structure in the South African context provides a fertile base to conduct additional empirical work with South African samples.

\section{Limitations}

As with most research endeavours, the present study has a number of limitations that need to be considered when 
interpreting the results. Firstly, the organisations employed for the study were targeted in terms of convenience and availability, limiting generalisability to all South African organisations. Although this is a limitation, it would be difficult to mitigate, as proposing any sample frame representative of a country would be contentious, and not all organisations included in the sample frame would be willing to participate in the study. The present sample presents an overrepresentation of women when considering the demographics of the South African workforce (Statistics South Africa 2016). This overrepresentation of women in the sample was deemed to be an effect of the present sample, and it was thus not controlled for. A further limitation is that the reliability coefficients reported in the study are low - in fact substantially lower than those reported by Strydom (2013) during the development of the BCEAI. This places a damper on the results. The low reported reliabilities is likely to inhibit the use of the instrument.

\section{Conclusion}

The results provide ample evidence of measurement invariance of the BCEAI across gender in the workplace context in South Africa and also support the veracity and stability of the CEAI model among job incumbents in the country. The results further suggest that it is warranted for researchers and practitioners to tap into the accumulated wealth of empirical and theoretical knowledge associated with the CEAI model. After establishing measurement invariance, it will be appropriate for researchers to proceed with testing substantial hypotheses about the means and interrelations between latent constructs across groups (Hirschfeld \& Von Brachel 2014). This will advance enquiries into the evaluation of entrepreneurial climate, the prediction of innovation, as well as studies directed towards the identification of gender as a moderator in this context.

\section{Acknowledgements}

The authors gratefully acknowledge the assistance of the MBL class of 2014 for collecting the data and the SBL-REC for allowing access to the data used in this study. The project was partly funded through the National Research Foundation's Incentive Funding for Rated Researchers.

\section{Competing interests}

The authors declare that they have no financial or personal relationships that may have inappropriately influenced them in writing this article.

\section{Authors' contributions}

Both authors contributed to the conceptualisation of the article with R.S. mainly responsible for the literature review and conclusions and G.P.d.B. responsible for the statistical analysis and discussion of the results.

\section{References}

Adams, R. \& Ferreira, D., 2009, 'Women in the boardroom and their impact on governance and performance', Journal of Financial Economics 94, 291-309. https://doi.org/10.1016/j.jfineco.2008.10.007

Baker, B., Caison, A. \& Meade, A., 2007, 'Assessing gender-related differential item functioning and predictive validity with the Institutional Integration Scale', Educational \& Psychological Measurement 67(3), 545-559. https://doi.org/10.1177/ 0013164406292088

Bennie, C. \& Huang, T., 2010, 'Gender differences in stress management, emotional management and emotional expression within the workplace', New Voices in Psychology 6(2), 23-44.

Bhardwaj, B.R., 2012, 'Internal environment for corporate entrepreneurship: Assessing CEAl model for emerging economies', Journal of Chinese Entrepreneurship 4(1), 70-87. https://doi.org/10.1108/17561391211200948

Bigliardi, B., 2013, 'The effect of innovation on financial performance: A research study involving SMEs innovation', Management, Policy \& Practice 15(2), 245-256. https://doi.org/10.5172/impp.2013.15.2.245

Björkdahl, J. \& Börjesson, S., 2011, 'Organizational climate and capabilities for innovation: A study of nine forest-based Nordic manufacturing firms', Scandinavian Journal of Forest Research 26(5), 488-500. https://doi.org/10.1080/02827581.20 11.585997

Brazeal, D.V., Schenkel, M.T. \& Kumar, S., 2014, 'Beyond the organizational bounds in $\mathrm{CE}$ research: Exploring personal and relational factors in a flat organizational structure', Journal of Applied Management and Entrepreneurship 19(2), 78-106, viewed 07 March 2017, from http://search.proquest.com/docview/1543780446? accountid $=14648$

Cascio, W.F., 2015, Managing human resources: Productivity, quality of life, profits, 10th edn., McGraw-Hill Irwin, Boston, MA.

Chen, F.F., 2008, 'What happens if we compare chopsticks with forks? The impact of making inappropriate invariance', Structural Equation Modeling 9(2), 233-255.

Deloitte, 2013, Innovation and idea generation are the top outcomes from gender diversity, according to Deloitte's International Women's Day survey, viewed 15 July 2016, from https://www2.deloitte.com/global/en/pages/about-deloitte/articles/ innovation-idea-generation-deloittes-international-womens-day-survey.html

De Villiers-Scheepers, M.J., 2012, 'Antecedents of strategic corporate entrepreneurship', European Business Review 24(5), 400-424. https://doi.org/ 10.1108/09555341211254508

Durán-Vázquez, R., Lorenzo-Valdés, A. \& Moreno-Quezada, G.E., 2012, 'Innovation and CSR impact on financial performance of selected companies in Mexico', Journal of Entrepreneurship, Management and Innovation 8(3), 5-20. https://doi. org/10.7341/2012831

Frame, M.C., Roberto, K.J., Schwab, A.E. \& Harris, C.T., 2010, 'What is important on the job? Differences across gender, perspective, and job level', Journal of Applied Social Psychology 40, 36-56. https://doi.org/10.1111/j.1559-1816.2009.00562.x

Francoeur, C., Labelle, R. \& Sinclair-Desgagné, B., 2008, 'Gender diversity in corporate governance and top management', Journal of Business Ethics 81, 83-95. https:// doi.org/10.1007/s10551-007-9482-5

Hajipour, B. \& Mas'oomi, S., 2011, 'A survey on the relationship between financial performance and corporate venturing', Interdisciplinary Journal of Contemporary Research in Business 2(12), 890-901, available from http://search.proquest.com/ docview/876011441 ?accountid $=14648$

Hamidianpour, F., Esmaeilpour, M., Alizadeh, M.S. \& Dorgoee, A., 2015, 'The influence of emotional intelligence and organizational climate on creativity and entrepreneurial of small to medium-sized enterprises', European Online Journal of Natural and Social Sciences 4(1), 20-30.

Hirschfeld, G. \& Von Brachel, R., 2014, 'Improving multiple-group confirmatory factor analysis in R: A tutorial in measurement invariance with continuous and ordinal indicators', Practical Assessment, Research \& Evaluation 19(7), viewed 07 March 2017, from http://pareonline.net/getvn.asp?v=19\&n=7

Holt, D.T., Rutherford, M.W. \& Clohessy, G.R., 2007, 'Corporate entrepreneurship: An empirical look at individual characteristics, context, and process', Journal of Leadership \& Organizational Studies 13(4), 40-54, available from http://search. proquest.com/docview/203135466? accountid $=14648$

Hornsby, J.S., Kuratko, D.F., Holt, D.T. \& Wales, W.J., 2013, 'Assessing a measurement of organizational preparedness for corporate entrepreneurship', The Journal of of organizational preparedness for corporate entrepreneurship', The Journal of
Product Innovation Management 30(5), 937, available from http://search. proquest.com/docview/1424397432?accountid=14648

Hornsby, J.S., Kuratko, D.F. \& Zahra, S.A., 2002, 'Middle managers' perception of the internal environment for corporate entrepreneurship: Assessing a measurement scale', Journal of Business Venturing 17(3), 253-273. https://doi.org/10.1016/ S0883-9026(00)00059-8

Jiménez, J.M., Fuentes-Fuentes, M.M. \& Ruiz-Arroyo, M., 2014, 'Knowledge combination capability and innovation: The effects of gender diversity on top management teams in technology-based firms', Journal of Business Ethics. https:// doi.org/10.1007/s10551-014-2462-7

Kamffer, L., 2004, 'Factors impacting on corporate entrepreneurial behaviour within a retail organisation - A case study', Doctor of Philosophy, University of Pretoria, Pretoria, South Africa.

Karimi, A., Malekmohamadi, I., Daryani, M.A. \& Rezvanfar, A., 2011, 'A conceptual model of intrapreneurship in the Iranian agricultural extension organization', Journal of European Industrial Training 35(7), 632-657. https://doi.org/10.1108/ 03090591111160779

Kuratko, D.F. \& Audretsch, D.B., 2013, 'Clarifying the domains of corporate entrepreneurship', International Entrepreneurship and Management Journal 9(3), 323-335. https://doi.org/10.1007/s11365-013-0257-4 
Kvidal, T. \& Ljunggren, E., 2014, 'Introducing gender in a policy programme: A multilevel analysis of an innovation policy programme', Environment and Planning 32(1), 39-53. https://doi.org/10.1068/c11207r

Likar, B., Kopa, J. \& Fatur, P., 2014, 'Innovation investment and economic performance in transition economies: Evidence from Slovenia', Innovation: Management, Policy \& Practice 16(1), 53-66. https://doi.org/10.5172/impp.2014.16.1.53

Lin, C.Y. \& Liu, F., 2012, 'A cross-level analysis of organizational creativity climate and perceived innovation', European Journal of Innovation Management 15(1), 55-76. https://doi.org/10.1108/14601061211192834

Marzban, S., Seyed, M.M. \& Ramezan, M., 2013, 'The effective factors in organizational entrepreneurship climate', Journal of Chinese Entrepreneurship 5(1), 76-93. https://doi.org/10.1108/17561391311297897

McMahon, A.M., 2010, 'Does workplace diversity matter? A survey of empirical studies on diversity and firm performance, 2000-09', Journal of Diversity Management 5 , 37-48.

Mellenbergh, G.J., 1989, 'Item bias and item response theory', International Journal of Educational Research 13, 127-143. https://doi.org/10.1016/0883-0355(89)90002-5

Meredith, W., 1993, 'MI, factor analysis and factorial invariance', Psychometrika 58, 525-543. https://doi.org/10.1007/BF02294825

Meredith, W. \& Millsap, R.E., 1992, 'On the misuse of manifest variables in the detection of measurement invariance', Psychometrika 57(2), 289-311. https:// doi.org/10.1007/BF02294510

Mikkola, M., 2016, 'Feminist perspectives on sex and gender', in E.N. Zalta (ed.), The Stanford Encyclopedia of Philosophy, pp. 1-25, viewed 15 July 2016, from http:// plato.stanford.edu/archives/spr2016/entries/feminism-gender/

Mühlau, P., 2011, 'Gender inequality and job quality in Europe', Management Revue 22(2), 114-131.

Ndregjoni, Z. \& Elmazi, L., 2012, 'The effects of relationship between information technology and firm innovation on firm performance: The case of Albania', International Journal of Management Cases 14(1), 235-246. https://doi.org/ 10.5848/APBJ.2012.00023

Nikolov, K. \& Urban, B., 2013, 'Employee perceptions of risks and rewards in terms of corporate entrepreneurship participation', SA Journal of Industrial Psychology 39(1), 1-13, available from http://search.proquest.com/docview/1440188031?ac countid $=14648$

Nusair, T.T., 2013, 'The role of climate for innovation in job performance: Empirical evidence from commercial banks in Jordan', International Journal of Business and Social Science 4(3), 208-217.

Nybakk, E. \& Jenssen, J.I., 2012, 'Innovation strategy, working climate, and financial performance in traditional manufacturing firms: An empirical analysis', International Journal of Innovation Management 16(2), 1-26. https://doi.org/ 10.1142/S1363919611003374

Oke, A., Walumbwa, F.O. \& Myers, A., 2012, 'Innovation strategy, human resource policy, and firms' revenue growth: The roles of environmental uncertainty and
innovation performance', Decision Sciences 43(2), 273-302. https://doi.org/ innovation performance', Decision
10.1111/j.1540-5915.2011.00350.x

Padmaja, B., 2014, 'Organizational climate as a predictor of job satisfaction of employee: A case study with special reference to electricity employees', International Journal of Organizational Behaviour and Management Perspectives 3(4), 1350-1356.

Panuwatwanich, K., Stewart, R.A. \& Mohamed, S., 2008, 'Enhancing innovation and firm performance: The role of climate for innovation in design firms', Proceedings of the 5 th International Conference on Innovation in Architecture, Engineering and Construction, Antalya, Turkey, 23-25 June.

Parrotta, P., Pozzoli, D. \& Pytlikova, M., 2014, 'The nexus between labor diversity and firm's innovation', Journal of Population Economics 27(2), 303-364. https://doi. org/10.1007/s00148-013-0491-7
Pässler, K., Beinicke, A. \& Hell, B., 2014, 'Gender-related differential validity and differential prediction in interest inventories', Journal of Career Assessment 22(1), 138-152. https://doi.org/10.1177/1069072713492934

R Core Team., 2013, R: A language and environment for statistical computing, $\mathrm{R}$ Foundation for statistical computing, Vienna, Austria, viewed 12 April 2017, from http://www.R-project.org/

Robbins, S.P. \& Judge, T.A., 2011, Organizational behaviour, 14th edn., Pearson/ Prentice Hall, Upper Saddle River, NJ.

Rosseel, Y., 2012, 'Lavaan: An R package for structural equation modeling', Journal of Statistical Software 48(2), 1-36, available from http://www.jstatsoft.org/v48/i02/

Salzberger, T., Newton, F.J. \& Ewing, M.T., 2014, 'Detecting gender item bias and differential manifest response behavior: A Rasch-based solution', Journal of Business Research 67(4), 598-607. https://doi.org/10.1016/j.jbusres.2013. 02.045

Sonfield, M., Lussier, R., Corman, J. \& McKinney, M., 2001, 'Gender comparisons in strategic decision-making: An empirical analysis of the entrepreneurial strategy strategic decision-making: An empirical analysis of the entrepreneurial strategy
matrix', Journal of Small Business Management 39(2), 165-173, available from matrix', Journal of Small Business Management 39(2), 165-173, a
http://search.proquest.com/docview/221000105?accountid=14648

Statistics South Africa, 2016, Quarterly employment statistics, viewed 17 January 2017 from http://www.statssa.gov.za/publications/P0277/P0277September2016.pdf

Stegerean, R. \& Gavrea, C., 2010, 'Innovation and development: Criteria for organizational performance', Managerial Challenges of the Contemporary Society 1, 202-205.

Strydom, A.S., 2013, 'The influence of organisational behaviour variables on corporate entrepreneurship', Doctor of Business Leadership, University of South Africa, Pretoria, South Africa.

Van Wyk, R. \& Adonisi, M., 2011, 'An eight-factor solution for the Corporate Entrepreneurship Assessment Instrument', African Journal of Business Management 5(8), 3047-3055.

Vandenberg, R.J. \& Lance, C.E., 2000, 'A review and synthesis of the measurement invariance literature: Suggestions, practices, and recommendations for organizational research', Organizational Research Methods 3, 4-70. https://doi.org/ $10.1177 / 109442810031002$

Wei, T., Chesnut, S.R., Barnard-Brak, L., Stevens, T. \& Olivárez, Jr, A., 2014 'Evaluating the mathematics interest inventory using item response theory: Differential item functioning across gender and ethnicities', Journal of Psychoeducational Assessment 32(8), 747-761. https://doi.org/10.1177/07342 82914540449

Wetzel, E., Böhnke, J.R., Carstensen, C.H., Ziegler, M. \& Ostendorf, F., 2013, 'Do individual response styles matter? Assessing differential item functioning for men and women in the NEO-PI-R', Journal
doi.org/10.1027/1614-0001/a000102

Wu, A.D., Li, Z. \& Zumbo, B.D., 2007, 'Decoding the meaning of factorial invariance and updating the practice of multi-group confirmatory factor analysis: A and updating the practice of multi-group confirmatory factor analysis: A 12(3), available from http://pareonline.net/getvn.asp?v $=12 \& n=3$

Yen, Y., 2013, 'The impact of bank's human capital on organizational performance: How innovation influences performance', Innovation: Management, Policy \& Practice 15(1), 112-128. https://doi.org/10.5172/impp.2013.15.1.112

Zampetakis, L.A., Bakatsaki, M., Litos, C., Kafetsios, K.G. \& Moustakis, V., 2017, 'Gender-based differential item functioning in the application of the theory of planned behavior for the study of entrepreneurial intentions', Frontiers in Psychology 8, 451. https://doi.org/10.3389/fpsyg.2017.00451

Zhang, Y. \& Begley, T.M., 2011, 'Power distance and its moderating impact on empowerment and team participation', The International Journal of Human Resource Management 22, 3601-3617. http://dx.doi.org/10.1080/09585192.201 1.560877 